\title{
Now Disease Reports \\ Characterisation of a phytoplasma associated with Petunia witches' broom disease in Iran
}

M.M. Faghihi ${ }^{1}$, S.M. Taghavi ${ }^{1}$, M. Salehi ${ }^{2}$, M.S. Sadeghi ${ }^{1}$, S. Samavi ${ }^{3}$ and M. Siampour ${ }^{4}$

${ }^{1}$ Department of Plant Protection, College of Agriculture, Shiraz University, Shiraz, Iran; ${ }^{2}$ Fars Agriculture and Natural Resources Research Center, P.O.Box: 1151-71955, Iran; ${ }^{3}$ Hormozgan Agriculture and Natural Resources Research Center Iran; ${ }^{4}$ Department of Plant Protection, College of Agriculture, Shahrekord University, Shahrekord, Iran

*E-mail: faghihi.mm@gmail.com

Received: 11 Feb 2014. Published: 03 Nov 2014

Petunia hybrida (Solanaceae) is an economically important ornamental plant species that is used in residential and commercial landscapes. Varieties are diverse and available in a range of colours (Abu-Qaoud et al, 2010; Hiuts et al, 1994). In July 2012, symptoms of witches' broom, yellowing, little leaf, phyllody and virescence were observed in Petunia in Sistan and Baluchestan province, Iran (Fig. 1a, b). Total DNA was extracted separately from $0.5 \mathrm{~g}$ of shoot material of two symptom-bearing and one symptomless plant (Fig. 1c) using a modified cetyltrimethylammonium bromide (CTAB) method (Doyle \& Doyle, 1990). The samples were analysed for detection of phytoplasma DNA by both direct and nested PCR assays using phytoplasma universal 16S rDNA primer pairs $\mathrm{P} 1 / \mathrm{P} 7$ and R16F2n/R16R2 that amplify fragments of $1800 \mathrm{bp}$ and $1250 \mathrm{bp}$, respectively (Lee et al., 1998). The 1800 and $1250 \mathrm{bp} \mathrm{PCR}$ products were obtained following direct and nested PCR from all symptombearing but not from symptomless plants. The 1250 bp PCR product was directly sequenced. BLAST analysis of the partial 16S rDNA sequence (GenBank Accession No. JX570935) revealed that the phytoplasma associated with Petunia witches' broom (PtWB) shared 100\% identity with some phytoplasmas related to $16 \mathrm{Sr}$-II phylogenetic group, 'Candidatus Phytoplasma aurantifolia', such as chickpea phyllody phytoplasma (FJ870549.1), tomato big bud phytoplasma (JQ868448), 'Ca. P. aurantifolia' (JX104335) and Echinacea witches' broom phytoplasma (JF340075.1). This result was further confirmed by the analysis using iPhyClassifier online tool (http://www.plantpathology.ba.ars. usda.gov/cgibin/resource/iphyclassifier. cgi) where it was determined that PtWB phytoplasma is related to $16 \mathrm{Sr}$ group-II, subgroup D. The

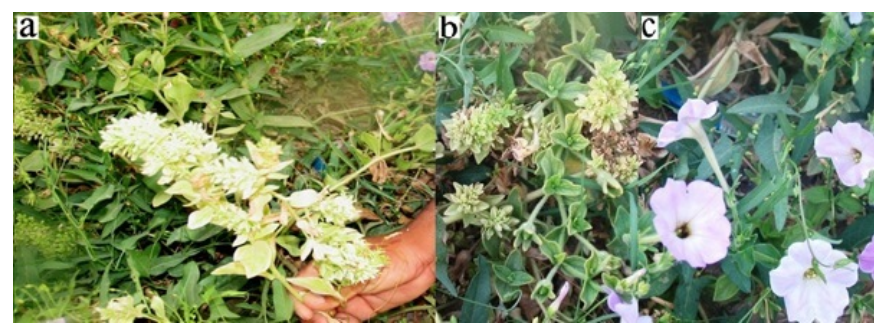

phylogenetic neighbour-joining tree (MEGA 5 software) based on the partial 16S rDNA sequences (1250 bp) of the PtWB phytoplasma and several reference phytoplasmas corroborated these results and showed that PtWB phytoplasma is closely related to 'Candidatus Phytoplasma australasiae' in the 16Sr-II phytoplasma clade (Fig. 2). Salehi et al. (unpublished) have recently detected a phytoplasma associated with phyllody symptoms in Petunia by PCR in Fars province, Iran. However, this is the first report of molecular characterisation of a phytoplasma associated with PtWB disease in Iran.

\section{References}

Abu-Qaoud H, Abu-Rayya A, Yaish, S, 2010. In vitro regeneration and somaclonal variation of Petunia hybrida. Journal of Fruit and Ornamental Plant Research 18, 71-81.

Doyle JJ, Doyle JL, 1990. A rapid total DNA preparation procedure for fresh plant tissue. Focus 12, 13.

Huits SM, Gerats, AGM, Kreike MM, Mol JMN, Koes RE, 1994. Genetic control of dihydro-flavonol 4-reductase gene expression in Petunia hybrida. The Plant Journal 6, 295-310.

Lee IM, Gundersen-Rindal DE, Davis RE, Bartoszyk IM, 1998. Revised classification scheme of phytoplasmas based an RFLP analyses of 16S rRNA and ribosomal protein gene sequences. International Journal of Systematic Bacteriology 48, 1153-1169.

http://dx.doi.org/10.1099/00207713-48-4-1153

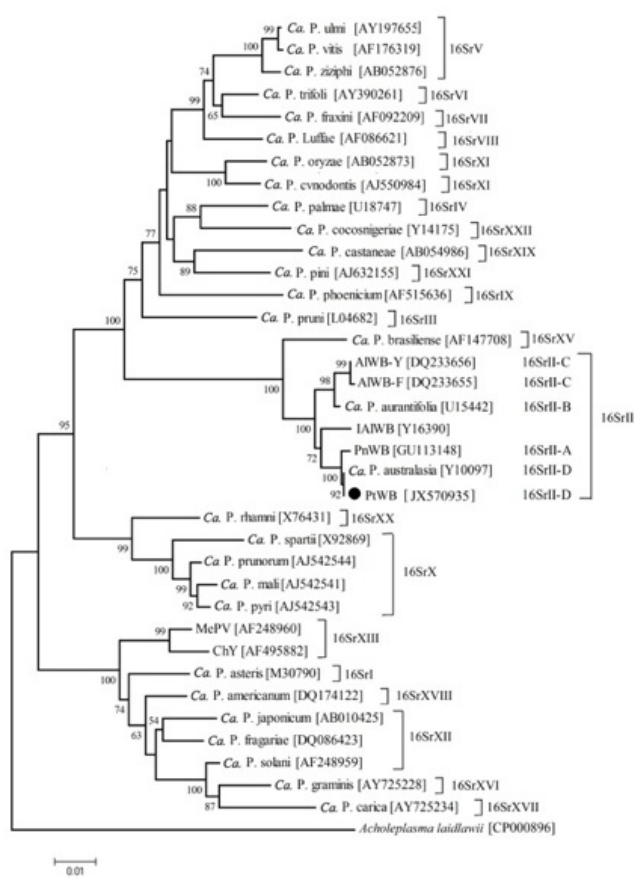

Figure 2

To cite this report: Faghihi MM, Taghavi SM, Salehi M, Sadeghi MS, Samavi S, Siampour M, 2014. Characterisation of a phytoplasma associated with Petunia witches' broom disease in Iran. New Disease Reports 30, 21. http://dx.doi.org/10.5197/j.2044-0588.2014.030.021 (c) 2014 The Authors 